\title{
Being ready for the next Uber: can local government reinvent itself?
}

\author{
Tom Cohen
}

\begin{abstract}
The history of Uber's interaction with local and national governments is surveyed to provide a case study for the wider issue of the governance of private-sector involvement, technological innovation and disruption in the mobility sector. Uber's tenacious and highly competitive approach to building markets is identified as a significant challenge to authorities and the limited power they have over Uber (beyond simply refusing access) is acknowledged. Uber's entry into the delivery of statutory services is identified as a particularly striking development. The case of Uber provides useful insights concerning technological innovation and disruption, but more important is the company's business model. The analysis enables some findings concerning how authorities can prepare for the "next" Uber: these include working on preparedness (by conducting futures work, for example); on standing arrangements (such as insisting on an open data model); and on responding to the entry of a challenging provider or service, through the use of experimental legislation.
\end{abstract}

Keywords: Uber, Competition, Innovation, Disruption, Governance, Regulation

\section{Introduction}

The rich discipline of Public Policy has produced a profusion of models and theories designed to explain the process of policy making and governance more generally and to provide guidance to those seeking to improve on past practice. Notable figures are Herbert Simon [48], who introduced the concept of bounded rationality, Lindblom [33] who spoke of "muddling through", and Easton [15] who attempted to apply a more formal structure to the policy analysis process.

What would these giants make of the events of the last six years involving the rise of Uber in the international sphere of urban transport? Would they, as some current commentators, be counselling more extensive regulation to keep the organisation in check? Or might they argue the opposite, that innovation needs to be allowed to flourish and can only do so if unfettered? We will later use as our reference the work of Lindblom and, in particular, his contraposition of "scientific analysis" and incrementalism [33, 34]. He characterises the former as the assessment of all possible options against a

Correspondence: tom.cohen@ucl.ac.uk

Centre for Transport Studies, University College London, Chadwick Building, Gower Street, London WC1E 6BT, United Kingdom comprehensive statement of objectives or values and the latter as a more pragmatic and continual exercise of considering typically modest adjustments to the policy direction by asking whether they would constitute an improvement on the status quo. One of Lindblom's main arguments against scientific analysis was that, with the exception of quite narrowly defined policy questions, it is impossible to know in advance all the impacts of a course of action. A reason for this is of course the uncertainty associated with the future, a subject rather less discussed then than now, though Dror, one of Lindblom's contemporaries, was arguing in the same era for concerted futures work to feature in policy making [12]. Nor did Lindblom much address the issue of external events affecting an authority's capacity to respond, though we might expect him to offer these as further evidence in favour of incrementalism, his preferred method of formulating policy.

Returning to Uber, what our discussion will first demonstrate is that authorities have reacted in very different ways to it. For example, at the time of writing, having announced that it would not renew Uber's licence to operate as a private hire company, Transport for London is now engaged in a lengthy judicial process with Uber 
over whether the latter is "fit and proper" to hold a licence ([59]; [29]). Many other cities, having posed few obstacles to Uber's arrival, are now attempting to rein the company in. Second, and more important for this paper, is the challenge that Uber has posed to the policy-making process, demonstrating its limitations when responding to technological advance or in fact, as we shall argue, aggressive business practices. We shall see a familiar conflict - that between ensuring innovation and "maximising the network benefits of operating an overall transport system" ([30], p. 25). We shall also see a tentativeness on government's part, reflecting a more general tendency for public policy to lag behind changes in the operating environment.

And these developments are played out against a background of differing philosophies concerning the roles and merits of innovation, entrepreneurship, competition and regulation; they also prompt reflection on the potential benefits of the "sharing economy" and whether, in fact, Uber deserves to be included in it [53]. It turns out that Uber provides a very useful case study not just for the governance of new technology in transport, but of the wider relationship between the public and private sectors.

The paper begins with a survey of the relationship between Uber and local and national governments since it entered the ride-hailing business in 2012. This is then used as the basis for some reflections on the nature of that relationship and the lessons it offers. The paper ends with some specific suggestions of what authorities could do differently in future in order to manage the next Uber more successfully.

\section{Uber and authorities - a brief history}

Uber started operating in something like its current form in 2012, having run a limousine service in San Francisco before developing so-called "ride-hailing"1 (or "ride-sharing") now generally seen as a competitor to conventional taxi or private hire. It was not the first to become a ride-hailing provider, and Lyft remains a source of competition in the USA, but its current overall dominance of the international market is not in doubt [18].

Uber arrived in an already complex and (it is argued) dysfunctional market and elicited very different responses from policy makers. We discuss these points in turn. And the market place within which Uber operates has not stood still since 2012, with growth in many of its locations in the number of limousines a noteworthy development.

Whilst much of what is written about Uber is critical (Morozov [36] and Harris [24] are just two examples), it has its defenders, most notably its customers, whose support the company has enlisted on numerous occasions in order to strengthen its case to be allowed to operate, sometimes successfully, sometimes not [43]. According to Posen [38], Uber gladly negotiates with city policy makers in advance of launching, and in fact it was officially registered with London's transport authority Transport for London (TfL) - when it commenced operations there in 2012 [13]. Against this background though, Uber is prepared to press on with launching in the face of city resistance and is claimed to have operated in San Francisco using a loophole in taxi regulations [18]. These facts, together with the extensively reported battles over the employment status of its drivers, have earned it a reputation for being aggressive, or at least for finding it "easier to ask forgiveness than permission" [60].

\subsection{The taxi/private hire market before and since Uber}

The growth of Uber needs to be considered in the context of the markets it has entered. For example, in San Francisco, the taxi market was notoriously poor from the customer's perspective [18]. Users had to wait a long time for a cab (if they were able to book one in the first place) and paid high fares when it arrived. In economic terms, then, this was a natural target market for new entrants.

Taxi services were unregulated when they first began over a century ago; regulation was brought in to protect road users from the safety impacts of poor driving and the sometimes violent conduct of drivers vying for business [38]. But the regulation, which initially took the form of limiting the number of drivers, developed in a variety of ways over time and location. According to Bekken [4], writing before the advent of Uber and its ilk, there are three categories: direct barriers to entry (principally quantitative and qualitative regulations on the operators); indirect barriers to entry (of which driver requirements and vehicle requirements are obvious examples); and fare regulations. This is close to the four-fold structure adopted by International Transport Forum Corporate Partnership Board [27] in its deliberations: public safety rules (including insurance); market entry conditions; service requirements; and fares. In this context, Darbéra [11] offers a useful clarification based on the distinction between the French words régulation and réglementation: regulation is the business of ensuring that a given market "works" in some agreed sense by imposing a set of economic controls. Deregulation, the removal of some or all of those controls, will not tend to mean the disappearance of all rules and laws (réglementation), and will probably instead imply a range of new ones to promote competition.

To some, regulation has lost its benign roots and today is a mechanism for earning revenue for city governments through the charging of supra-competitive rates [20], or for shoring up the privileged positions of 
those who have operator licences [27]. This varied perception of regulation around the world has led to deregulation in different ways and to differing degrees. For example, New Zealand (1989), Sweden (1990) and the Netherlands (2000) all deregulated their taxi markets $[4,50]$. Elsewhere, it is common to see taxis (in the sense of vehicles that can be hailed on street) treated differently from private hire vehicles (PHV) which must be booked in advance of a journey, something which until recently tended to happen through despatch centres. The taxi market tends to be more tightly regulated than the PHV market, with fare limits, maximal numbers of vehicles/licences/drivers and a range of entry and operating requirements that both ensure quality and, indirectly, control numbers. The rationale for this is that customers have less freedom to shop around when using a taxi that they hail on street and that they therefore need greater protection [4]. The advent of Uber and similar organisations have placed this approach in doubt, with arguments emerging in favour of fare regulation in the PHV market (which de facto includes Uber) [27].

Gabel [20] investigates the impact of Uber on the conventional taxi market in various US cities, arguing that private hire should display high elasticity because of the lack of sunk costs on the consumer's part and the absence of any meaningful loyalty mechanism. Put another way, the arrival of Uber might be expected to have dealt a massive blow to the conventional taxi. But, despite an appreciable decrease in the price of a medallion ${ }^{2}$ in several cities, he finds the conventional taxi to be holding up surprisingly well in the face of this challenge. As of 2015, Yellow Cabs continued to dominate the market in the New York City (though this may no longer be the case), a fact attributed to the one significant advantage they retain over Uber and its like - that it is possible to hail a vehicle on the street. The fact that using Uber requires ownership of a smart phone is a secondary reason.

The conventional taxi communities have fought hard in most of Uber's locations to expel the operator or, at least, to constrain it significantly. For example, taxi drivers in London attempted to prove that Uber drivers were using de facto meters. If the courts had agreed, Uber would be considered to be operating a conventional taxi service but without the necessary licences and would therefore be required to cease trading. In this case, the taxi lobby was unsuccessful [57].

The debate concerning Uber and the pre-existing market (taxis and PHVs) reflects several standpoints: Uber is variously seen as innovative and entrepreneurial [20] themes to which we shall return - and malign (see, for example, $[25,45])$. Some commentators (e.g. [21]) believe taxi drivers enjoy undue privilege; others (e.g. [25]) see them as a precarious sector of the workforce whose welfare requires protection from the likes of Uber. The balance of views differs across locations, with US writers tending more towards an anti-regulation stance, as demonstrated by Flores and Rayle, who claim that "in virtually all cities of the developed world, transportation services are highly regulated and new entrants face intense resistance" ([18], p. 3765). This range of views is reflected in the attitudes and behaviour of policy makers, to whom we now turn.

\subsection{How regulators respond to Uber}

San Francisco is a natural starting point for a survey of regulatory responses to Uber. We have already identified that the conventional taxi service there was considered extremely poor and this is thought to be one factor behind policy makers' tolerance of the new entrant. But perhaps more significant was a general enthusiasm for innovation and "high tech". Key city stakeholders saw ride-hailing firms as the right kind of company to nurture, first because this would provide a welcome additional means of transport for the city's residents and employees but also because it would send a positive message concerning San Francisco's readiness to embrace novelty, a key pillar of the city's growth plans. The mayor and others therefore made a concerted effort to stifle moves elsewhere in the city to contain or defeat Uber, Lyft etc., by tolerating the use of a legal loophole and escalating the matter to the state level, where there were similarly sympathetic individuals who enacted new legislation that enabled the companies' ongoing operation [18].

Singapore is another location which has been relatively benign in its treatment of Uber. Tham [56], who compares Singapore with Australia in terms of their respective treatment of Uber and Airbnb, concludes that Singapore may have been the more welcoming of the two towards Uber because of its established "high-tech" status and smart-city aspirations. He also picks out the weakness of the (conventional) taxi union and the state's political stability as factors. The second of these is plausible given that many politicians in other locations have had to negotiate a delicate path between appearing to undermine a well-established (and well-supported) industry and being seen to asphyxiate a highly popular service. This is not as much an issue where re-election is a relative formality. As part of its management of ride-hailing firms, the Singapore government brought them together in order to redraft relevant regulations. As a result, ride-hailing drivers "are required to undertake training, medical and character checks" ([56], p. 404). This collaborative approach may be unique.

In contrast with the above two examples, European countries have tended to be somewhat less welcoming. Dudley et al. cite "fierce battles" in France, Germany, 
Belgium and Italy ([13], p. 493), whilst Hungary's regulators expelled Uber from the country. In the UK, the picture is more mixed: Uber is now operating in all of the UK's principal urban areas and the UK government has chosen not to act in response to protests by taxi drivers. As mentioned above, Uber registered with TfL when it commenced London operations in 2012. Whilst the city authorities have not sought since to shut Uber down directly, the relationship has been tempestuous, with TfL attempting unsuccessfully to impose a five-minute wait time before rides could commence, and subsequently succeeding in imposing English-language and topography tests on drivers [13]. London's concern arises in part from the issue of congestion: analysis of traffic data indicates a considerable growth in the volume of "private hire vehicles", mirroring a large increase in the number of licensed drivers ([58], pp. 186-188). More recently, various members of TfL's board have expressed significant misgivings about the company's conduct, threatening to seek the revocation of its licence [51]. At the European level, cases in Spain and Belgium were referred up to the European Court of Justice, whose general advocate concluded that Uber is a transport company and not an information company [67], a conclusion which, if ratified by the Court itself, would oblige Uber to comply with national transport legislation.

Resistance to Uber is by no means limited to Europe. To give two examples, New York City was planning to impose a cap on the number of drivers who could drive for Uber put pulled back from doing this after a public dispute with the company [17]. And Seoul in South Korea has limited Uber to operating only its luxury limousines (i.e. not a service that would compete with conventional taxis), action that was seen as controversial given that many older and less wealthy Korean citizens are employed at the low end of the services sector [37]. Watanabe et al. [68] distil this range of examples into a binary model: in those locations that did not enter a legal battle (e.g. Singapore, Saudi Arabia and Tokyo), Uber induced a "consolidated challenge to social demand" producing a "co-evolution between [the] ride-sharing revolution and advancement of the institutional systems" ([68], p. 46). Legal battles were seen in, amongst other places, Germany, France and Italy, where a "traditional quasi-monopolistic market protected by non-innovative government impeded Uber's revolution resulting in disengagement from the institutional systems" ([68], p. 46).

The general pattern is that, if they do not ban it outright, authorities will struggle to control the behaviour of Uber. This presents cities with a real dilemma: excluding Uber and its ilk may mean missing out on some considerable transport and mobility benefits; but having no control over it may mean negative impacts upon existing transport systems in the short term, and more significant problems in the longer term (discussed below). Dudley et al. see nothing surprising in cities' plight: they argue that regulatory systems are necessarily reactionary but, perhaps more significant, that cities are forced to work with "frameworks that were never designed to deal with the types of technological and operational challenges presented by Uber ([61], p. 492)".

\subsection{The current situation}

At the time of writing, Uber's growth is continuing despite various problems with its public relations, including an incident that led to the resignation of its CEO, Travis Kalanick [31]. These include accusations of blocking certain users (including regulators) [3]. Nonetheless, the company remains popular with its users and other stakeholders: during its recent conflict with TfL in London, it orchestrated a petition that attracted 200,000 signatures and included the explicit support of prominent organisations such as the Institute of Directors [13]. The impression is that those authorities that allow Uber to begin operating are likely to see their capacity to influence it diminish as its market share grows, given its ability to marshal the assistance of drivers, riders and others to lobby on its behalf. This has led commentators to speculate concerning how Uber might conduct itself as and when it becomes dominant - might it employ "Ramsey pricing" (the charging of higher rates to those whose demand is inelastic, i.e. those who depend on it), for example [20]? This appears to be consistent with the use of so-called "surge pricing" which Uber justifies as a way of balancing supply and demand when the latter outstrips the former [62], but which has been widely criticised as monopolistic behaviour, leading to Uber acceding to demands to limit its multiplier in the USA to eight [27].

The most interesting aspect of the present situation is the blurring of boundaries between public and private sector, with Uber becoming involved in the provision of statutory transport in various US locations. In Florida, for example, Uber is being paid by the city of Altamonte Springs to reduce its fares for all citizens [63], with the goals of increasing the accessibility of residents and "complement transit options" [2]. The latter is promoted by offering a slightly larger discount for Uber trips to the local rail station. Styled as a public-private partnership, this development, as with most aspects of Uber, is attracting both praise and criticism. On the positive, the project is argued by the city and Uber to be a highly cost-effective way of meeting transport need (and avoiding expensive infrastructure investment); an initial pilot saw a significant increase in the volume of Uber trips [2]. Criticisms include the risk of subsidy leakage, the fact that Uber is unavailable to those without a smart 
phone and that the likely long-term outcome is the withdrawal of bus services on which the "homeless and poor" rely [35]. A particular concern - that Uber may obtain a dominant position - is dealt with through an undertaking by the city that any contract renewal would be open to other bidders [35]. The Florida example is not unique: in the Boston area, Uber was brought in as an alternative to the door-to-door van service for people with disabilities, despite the reservations of some users that few vehicles driven for Uber can accommodate wheelchairs [1]. That the taxi/PHV sector provides a proportion of the public sector's transport services is nothing new - Bekken [4] estimated the proportion as being above $25 \%$ in Belgium, Finland, the Netherlands, Hungary, Sweden and Norway - but the formal inclusion of Uber in public-sector transport services serves to legitimate the organisation and, in so doing, to imply that the numerous criticisms of its practices are either groundless or tolerable.

\section{Discussion}

In some respects, Uber is just another highly successful business enjoying exceptional growth. It is criticised for various aspects of its conduct but is not obviously behaving much worse than the average profit-seeking organisation. And initiatives such as its recent announcement that it will charge users to finance the decarbonisation of its fleet in London [61] may help to reduce criticism. But Uber is different from many other firms because its drivers and cars operate on the transport network, which is a shared resource. Further, whereas in the UK train operators pay to run trains on the rail network, Uber drivers pay very little to use the highways, a public resource managed by the state. If transport is seen as a utility, this private-sector organisation (and others doing similar business) is profiting from an asset that should be managed for the public good. It is also keeping its entry and exit costs low [21] because the infrastructure and equipment it uses are owned by others (the state, in the case of the highway and the driver in the case of the car). And this line of argument is one adopted by those who would like to see Uber much more tightly regulated.

Uber is frequently referred to as cheap, in that users pay less in London per unit distance than for practically any other form of private hire or taxi service. This helps to explain the company's extraordinary expansion. But there is more than one aspect of cost and, as London has detected, the substantial growth in use of Uber may have mixed effects. Where an Uber trip is replacing a private-car trip, the impact may be neutral or positive, depending on a variety of factors, including the power-trains and ages of the two vehicles in question. Where it is replacing a trip by conventional taxi, there may be a marginal benefit given evidence that Uber vehicles are used more intensively than taxis [10]. Where it is replacing a journey by public transport, this implies that the network is being used slightly less efficiently in terms of vehicle footprint and occupancy. If Uber is inducing traffic growth - creating trips - the benefits of the journeys to the individuals making them must be seen alongside the traffic, environmental and safety impacts that this new travel brings. In short, Uber's overall impact on the transport network and wider environment is complex and probably negative in net terms.

What of the future? If and when Uber becomes a monopoly in the private hire sector, will its fares remain low? Will it allow other entrants to undercut it? Will it become so powerful that it begins to set the transport policy agenda: "by taking its customers and its drivers as hostages, the monopolistic operator could even blackmail the local governments to shelve projects that might hurt its monopoly profits" ([11], p. 14). And, whereas in other sectors there tends to be a single regulator at state level (e.g. pharmaceuticals), transport is highly decentralised and individual authorities are more likely to succumb to local pressure than would a national body [21].

Writers who are supportive of Uber and who tend also to distrust structures that support established taxi services do not accept these assertions. Whilst they may want to see some regulation, this will tend to relate to protecting the physical safety of road users rather than the welfare of conventional taxi drivers or the smooth running of the highway network. Part of the enthusiasm for Uber lies in its rating system which is argued to provide a natural means of promoting good service as well as rooting out poor performance. Walker Smith, for example, sees the Uber model being replicated, with "trust" distributed and secured "from the bottom up by community consensus" ([66], p. 389), providing further evidence of the polarisation amongst commentators: those who favour the free market applaud the "creative disruption" [46] Uber has brought and celebrate the dismay that it has caused amongst what they see as vested interests (the established taxi market). These same writers are not keen on regulation (except to the extent that it protects the safety of users) and so do not express concern over the way Uber is affecting the governance of transport in cities. A perhaps more balanced view emerged from an ITF round table on the subject which was attended by representatives of governments and the various elements of the taxi/PHV industry, including Uber. Its conclusion was that equitably improving mobility, safety, consumer welfare and sustainability would "likely entail lightening entry controls for the for-hire transport market and fares regulation for dispatched taxi services. It will require continued oversight for services obtained via street hail/rank, which are marked by lack 
of effective consumer choice" ([27], p. 7). The question of whether Uber can and should be treated as if it were a conventional PHV company continues to be debated.

For their parts, city authorities are in a very difficult position once they have allowed Uber to start operating. If they act to constrain it, they are pilloried for frustrating public demand; if they allow Uber free rein, equally they are criticised for allowing an industry to suffer and a profit-seeking organisation to indulge in unscrupulous business practices. Does this mean that cities cannot win? And, if this is the case where Uber is concerned, what about the next disruption? We discuss this in the following section.

\subsection{Learning from the case of Uber}

\subsubsection{Themes of innovation, competition, entrepreneurialism and regulation}

The case of Uber is interesting not just because of the facts but because of the underlying concepts and the reactions they evoke in policy makers and commentators. We discuss some of these here.

We should begin with the theme of innovation as it is central to the Uber story. In San Francisco, the perception that Uber (and its counterparts) were innovative was crucial to the decision of key stakeholders to enable its development. Innovation is very widely seen as a good thing, especially in the USA [38] and this is easy to understand. How innovative Uber truly is, though, is another matter. In fact, the significant point is that Uber was perceived to be innovative and this was enough. If innovation is meaningful, it begets change and change almost inevitably involves a mixture of costs and benefits. The costs associated with adjustment will generally be accepted if the new status quo is considered an improvement on what went before. Some of the discussion above shows that commentators are divided on whether the new status quo including Uber is better than what it has replaced. Meanwhile, the adjustment costs - at the very least a restructuring of the private hire industry - are welcomed by some who dislike what they see as its protectionist ways.

Turning to competition, Uber presents a very interesting case but it is far from unique. The narrative that big auto conspired to kill off streetcars in major American cities is highly exaggerated but the major car firms did seek to control public transit [49] and this serves to remind us that competition is about attempting to put one's competitors out of business. The consumer benefits from competition for as long as this does not happen.

As with innovation, competition has its supporters and its detractors, with the former more prominent in the USA than in Europe. Again, it is easy to see why, Adam Smith having made the arguments almost 250 years ago ([52] [1776]). And the polarised response to
Uber could be expected to be replicated when the next major challenge to the transport equilibrium arrives: those favouring competition will expect it to ensure that the new entrant obtains a market share that reflects the quality of their offer; those who are more nervous of the operation of the market will worry that the new entrant is incentivised to act in such a way as to become dominant, with unfortunate consequences for many involved. In other words, critics of Uber see it as aggressive and unscrupulous whereas its supporters might choose words such as entrepreneurial and creative instead.

We turn, finally, to regulation, already much discussed in the context of Uber. For some, regulation is to be avoided wherever possible. As Geradin puts it: "Competition authorities...have an important role to play through competition advocacy. It is an important part of their mission to ensure that public authorities do not adopt or maintain regulatory frameworks that restrict competition" ([21], p. 29). Some see regulation as a means of ensuring fair competition and little more whereas the more interventionist thinkers would see it as an essential tool of governance, used to steer economy and society along a desirable path. Few, though, would see regulation as the friend of innovation.

\subsection{Uber and the sharing economy}

A further lens through which the Uber story has been told relates to the sharing economy $[5,54,55]$, the company often characterised as an exemplar in the context of a general proposition that the sharing economy is a "good thing". Whether Uber really is part of the sharing economy is moot and depends in large part on the prevailing definition of the term [14, 42, 45]. With the exception of UberPOOL, where strangers share a vehicle, Uber's services do not appear to demonstrate a greater degree of sharing than conventional taxi/PHV, wherein a driver "shares" the use of her/his vehicle with a paying customer. But, as with innovation, the point is less whether Uber really is part of the sharing economy than that it is characterised in this way: because the sharing economy is a "good thing", Uber's conduct may be treated slightly more leniently than would be case if it were painted simply as a "tech company". Moreover, the difficulties that have arisen with respect to Uber may even be laid at the door of regulatory deficiency: Cannon and Chung [6], for example, propose a new framework of co-regulation precisely to counter the problems that arise from the specificities of the technological sharing economy.

\subsection{The threat/opportunity of new technology and disruption}

This paper is predicated on an assumption that the Uber phenomenon is a sign of things to come. New transport 
products will increasingly emanate from the private or third sectors, offering opportunities and potential benefits, but at the same time presenting authorities with less scope for control than heretofore and thereby limiting their capacity to manage possible threats and disadvantages.

Disruption is naturally unsettling to all and this extends to transport policy makers, especially because many of the decisions they take relate to infrastructure and thus have very lengthy lifespans. In order for the building of a railway to be a "good" decision, there must be sufficient benefits flowing from the project to justify the costs. But what if new forms of mobility make the railway line redundant?

The case of Uber helps to demonstrate that new technology presents less of a challenge to authorities than what is done with that technology. The components of Uber's operation - smart phones enabled for payment, GPS, route-planning and scheduling software pre-existed the company's establishment, and Uber has not been the only firm to exploit them, with Lyft a strong competitor in the USA [8] and Didi Chuxing dominant in China [32]. What distinguishes Uber and its effect on transport networks is how the company has conducted itself, with its aggressive (or entrepreneurial) approach to growing its markets. But disruptors can be expected to continue to come from outside government, and they will vary in the extent to which their objectives align with those of city authorities. Thus, a technological advance may be observed but, until it is exploited, it constitutes neither a threat nor an opportunity. On occasion, authorities may be able to guide its exploitation but generally not, which means that they must wait to see who takes advantage and what the impact may be. More commonly, the technological advance will not be observed, or its potential impact will not be accurately predicted. San Francisco's authorities perceived a threat to the conventional taxi market from Uber, Lyft and Sidecar [18] but could not have been expected to foresee at that time the introduction of Uber into statutory transport provision. The taxi example does, however, point to one useful finding: industries or services that are not functioning well are natural targets for new entrants so transport authorities can at least examine their sector to identify areas that could be considered "at risk".

Another aspect of the Uber phenomenon that is common to the wider evolution of mobility as a service is the primary status of data. The transport impacts of Uber may be felt mainly on the network but its success as a business arises from the information it holds concerning people's travel behaviour and preferences. This information is highly prized and could be extremely useful to city authorities in planning and managing transport but it is not for the most part made available, except where such a requirement preceded Uber's arrival, as in the cases of New York City, London and the Netherlands, where the original motivation in making this stipulation was to enable efficient and robust monitoring of driver behaviour [11, 44]. It should not be taken for granted, however, that cities will know how to extract value from such data for the purposes of transport planning. To a lesser extent, software also represents a battleground, with providers looking to agree deals with authorities that are mutually advantageous and critics voicing concern that this in time will make cities hostages of the software providers [24].

\subsection{What authorities can do}

The examination of the case of Uber shows, amongst other things, that developments of this kind present authorities with great challenges. In this section, we discuss the extent to which these challenges can be overcome and which actions might achieve this.

But it is important to be as specific and realistic as possible: calls for "bold" public policies ([28], p. 9) are unhelpful, first because they are imprecise and, second, because what is "bold" to one observer may be "draconian" to another. Similarly, an instruction to create "an explicit market framework for new mobility markets" ([30], p. 24) disregards the fact that it is unlikely authorities will know early enough what these new mobility markets are.

So, attempting to be practical, we look at three aspects in turn: preparedness; standing arrangements; and response.

\subsubsection{Preparedness}

"You cannot predict the future but you can prepare for $i t$ " is a phrase reproduced with sufficient frequency to have made it a cliché. But, to the extent that it is true, what can authorities do to prepare for the future of mobility?

One answer is to conduct regular and methodical futures work [40, 64]. Shell famously introduced its scenario planning methods in the early 1970s and was as a result much better equipped to deal with the oil shock of 1973 than its competitors [65].

Part of standard futures work involves study of the past. As this survey of Uber has shown, there are lessons from previous events that can inform future approaches [7]. It can be helpful to range beyond the sector in question: what, for example, can the debates concerning personal health and genetic data and insurance tell us about the possible actions of the various parties in the mobility sector? And, where potential threats or opportunities are identified, authorities can usefully scope out their options in terms of response, and carry out a simple appraisal of their likely costs and benefits, as argued in the 
case of governing the advent of automated vehicles [9]. This may embolden authorities to regulate in advance, thereby achieving a degree of "anticipatory governance" of the kind generally discussed in the context of emerging technologies [23].

Less clear is whether authorities need to be reconstituted in order to meet future challenges [39]. Municipalities could recruit entrepreneurs and innovators, for example. This may better enable them to build effective structures within which entrants from the private and third sectors would be required to operate. (This assumes that the authority will not attempt to be the service provider itself, though this is what Seoul set out to do when it prevented Uber from operating its UberX service - [37].)

A final point is to repeat the observation that poorly performing sectors are ripe for attack by new entrants. Authorities can therefore usefully conduct an assessment of the mobility arena to identify such natural targets and focus their attention appropriately.

\subsubsection{Standing arrangements}

Can a municipality make the adoption of an open data standard a condition of providing services within its borders? This may prove tantamount to excluding a company such as Uber but would have the advantage of appearing a positive stance with respect to new entrants - through sharing data, we can all expect to gain. The requirement to share data has been managed successfully in certain of the locations discussed above but it must be noted that the stipulation was already in place before Uber began operating. A possible way of making such requirements more palatable would to be protect the commercial value of the data through anonymised querying systems such as MIT's SafeAnswers framework [26]. Having access to detailed and accurate data from the likes of Uber would first enable authorities to monitor conduct in order to promote compliance with relevant regulations and respond appropriately to transgressions. Second, it would provide a rich source of evidence to inform transport planning. This idea must not be taken lightly, of course. In this era of "big data", authorities may struggle to find the resources to make use of data collected by ride-hailing companies. This issue may be resolved in part by raising revenue from these companies; here the data could provide the mechanism to enable "smart charging" [22], whereby the charge levied would vary to reflect the pressure being imposed on the network, specific externalities, or some other policy concerns. The case of São Paulo is discussed in this regard below.

The example of Singapore provides another reference. In calling together ride-hailing providers and working collaboratively on regulations, it may have begun to create a less adversarial operating culture [68]. The scope of Singapore's dealings with the ride-hailing community was limited to issues of safety but there is no reason such a model could not be expanded in its coverage to include data, charging etc.

A final suggestion concerning standing arrangements is the sharing of experiences and ideas across cities and countries, a practice that becomes more relevant as private-sector stakeholders operate increasingly internationally. This could take the form of a simple on-line discussion forum but might lead to more formal collaborations such as CitySDK which "aims at harmonizing application programming interfaces (APIs) across cities” [19].

\subsubsection{Response}

The third category of action applies to situations in which Uber or its equivalent has arrived and is posing challenges from its position as an incumbent. This returns us to the subject of regulation and its appropriate application.

There is broad consensus that authorities already have available to them the tools necessary to restore some kind of equilibrium to the taxi/PHV market [27], though the precise nature of the appropriate intervention continues to be debated. It is, however, accepted that the existing set of policy measures is blunt and that a more efficient and targeted system of regulation could operate using, for example, detailed data concerning vehicle movements. This is the basis of legislation brought forward in the Brazilian city of São Paulo which, amongst other things, uses anonymised trip data as the basis for levying a charge on operators relating to distance travelled [47]. The European Commission is pursuing a similar path with respect to digital industries in general [16].

The more general point is that authorities should seek the most appropriate way of pursuing their objectives, being ready to go beyond the familiar set of policy instruments and perhaps using novel measures where this is justified.

The tendency for the public sector to be somewhat "flat-footed" in regulation has several causes but a major factor is its tendency to be risk-averse. Because regulation takes time to develop and implement, let alone revise, legislators often lag behind the events they are attempting to manage and resist pressure to "hurry legislation through". This norm is being resisted by some who advocate sunset clauses and, more generally, "experimental legislation" [41]. In summary, there are various ways in which law can be enacted relatively quickly and with an in-built ability to revise or withdraw it if it is found not to be delivering the desired outcome. In the context of Uber-like phenomena, unforeseen external developments may provide legislators with a justification for making such revisions. Posen proposes the use of 
time-limited experimental regulation to support user safety in particular: "the regulations should take on a flexible, experimental nature until the contours of the market are more fully developed" ([38], p. 329). The thinking is that this approach will allow all parties to learn what does and does not work on the way to setting permanent regulations at a future stage. Of course, this is easily said but may be difficult to realise. Uber, however, may have resisted somewhat less fiercely certain measures taken against it had they been explicitly experimental.

\section{Conclusion}

In concluding, we emphasise two points. First, authorities need to form a clear understanding of the possible impacts of a given development, be it Uber or something quite different, upon the communities they serve. In particular, they need to try to establish to what extent, and in which ways, the development will support or undermine the pursuit of their strategic objectives. This is a fundamental precursor to taking action.

Second, authorities need to recognise developments for what they are and respond accordingly. Uber is described as a technology innovator, a disruptor and a paradigm case of the sharing economy. Whilst all these may be true to a greater or lesser extent, what makes Uber significant for transport authorities is that it is an aggressive competitor which, through its backers and business model, is able to undercut the conventional private-hire/taxi market in numerous locations to a degree that has driven extremely rapid growth. The characterisation of Uber as innovator or paragon of the sharing economy has, we have argued, allowed criticisms of its conduct to be deflected to some degree so it is important for authorities not just to recognise the true character of new developments but also to call it out in what will inevitably be a very public debate. Future technology entrants may equally be innovators and/or exponents of the sharing economy but it will be the way in which they conduct their business that will determine their impact and it should therefore be this that determines the authority's response.

To close, let us turn back to Lindblom, whose arguments for incrementalism over what he termed scientific analysis we briefly summarised in the introduction. Though he wrote at a time when authorities perhaps had more confidence about their contextual environment than do their contemporaries, he nonetheless claimed that it was foolish to attempt to imagine and thoroughly assess all conceivable courses of action. His argument was that it was more pragmatic and, in fact, better in a broader sense, to judge possible courses of action by comparing them with the status quo. It is almost certain that he would see phenomena such as Uber as further evidence to support his case: the speedy emergence of game-changing actors surely makes the prospect of conducting scientific analysis all the more remote. We have discussed in this paper concepts such as innovative regulation, experimental legislation and anticipatory governance, all of which may have seemed unfamiliar to Lindblom. But we sense that he would have seen all of them as welcome aids in the business of "muddling through" [33].

\section{Endnotes}

${ }^{1}$ We shall use this term in this paper for the avoidance of confusion.

${ }^{2}$ The medallion entitles the owner to work as a taxi driver.

\section{Acknowledgements}

I am grateful to two anonymous reviewers for their helpful comments.

\section{Funding}

This paper is based on research carried out as part of the CREATE project, which has received funding from the European Union's Horizon 2020 research and innovation programme under grant agreement $N^{\circ} 636573$.

\section{Availability of data and materials}

Data sharing is not applicable to this article as no datasets were generated or analysed during the current study.

\section{Authors' contributions}

The author read and approved the final manuscript.

Competing interests

The author declares that he has no competing interests.

\section{Publisher's Note}

Springer Nature remains neutral with regard to jurisdictional claims in published maps and institutional affiliations.

Received: 25 June 2018 Accepted: 31 October 2018

Published online: 07 December 2018

\section{References}

1. Addady, M. (2016) Uber and Lyft Provide Accessible Transportation For Disabled People, Fortune.com. Available at: http://fortune.com/2016/09/18/ uber-lyft-accessible/ (Accessed: 14 Sept 2017).

2. Altamonte Springs FL. Uber. Available at: http://www.altamonte.org/index. aspx?nid=736 (Accessed: 14 Sept 2017).

3. BBC Technology (2017) 'Uber hides from regulators with Greyball', BBC News, 4 March. Available at: http://www.bbc.co.uk/news/technology39164880 (Accessed: 18 Sept 2017)

4. Bekken JT (2005) Experiences with regulatory changes of the taxi industry. 9th Conference on Competition and Ownership in Land Transport, Lisbon http://ses.library.usyd.edu.au/bitstream/2123/6151/1/thredbo9-workshopDBekken.pdf (Accessed: 4 Sept 2018

5. Belk R (2010) Sharing. J Consum Res 36(5):715-734. https://doi.org/10.1086/ 612649.

6. Cannon B, Chung H (2015) A framework for designing co-regulation models well-adapted to technology-facilitated sharing economies. Santa Clara High Technol Law J Santa Clara 31(1):23-96

7. Castles FG (ed) (1992) The comparative history of public policy. 2nd edn. Polity Press, Oxford

8. del la Cava M. (2017) Uber has lost market share to Lyft during crisis, USA Today. Available at: https://www.usatoday.com/story/tech/news/2017/06/ 13/uber-market-share-customer-image-hit-string-scandals/102795024/ (Accessed: 15 Sept 2017) 
9. Cohen T, Jones P, Cavoli C (2017) Social and behavioural questions associated with automated vehicles. Scoping study by UCL Transport Institute. Final report. Department for Transport, London https://www.gov. uk/government/uploads/system/uploads/attachment_data/file/582024/ social-and-behavioural-questions-associated-with-automated-vehicles-finalreport.pdf (Accessed: 12 Jan 2017

10. Cramer J, Krueger AB (2016) Disruptive change in the taxi business: the case of Uber. Am Econ Rev 106(5):177-182. https://doi.org/10.1257/aer. p20161002

11. Darbéra R (2015) Principles for the regulation of for-hire road transport passenger services. Corporate partnership board discussion paper. International Transport Forum, OECD, Paris

12. Dror $Y(1969)$ The role of futures in government. Futures 1(1):40-46. https:// doi.org/10.1016/S0016-3287(69)80006-6

13. Dudley G, Banister D, Schwanen T (2017) The rise of Uber and regulating the disruptive innovator. Polit Q 88(3):492-499. https://doi.org/10.1111/ 1467-923X.12373

14. Dupuis N (2018) Stories of the sharing economy: policy narratives surrounding the entry of transportation network companies into four midsized American cities. Crit Policy Stud 0(0):1-22. https://doi.org/10.1080/ 19460171.2018 .1437459$.

15. Easton D (1979) A framework for political analysis. University of Chicago Press (A Phoenix book, Chicago, p P834

16. European Commission Taxation and Customs Union (2018) 'Fair Taxation for the Digital Economy'. European Commission. Available at: https://ec.europa. eu/taxation_customs/business/company-tax/fair-taxation-digital-economy_ en (Accessed: 25 Sept 2018)

17. Fiegerman, S. (2015) Ethically, is Uber a better choice than a taxi?, Mashable UK. Available at: http://mashable.com/2015/07/25/uber-vs-taxis/\#var_ KjqDWsqB (Accessed: 12 Sept 2017)

18. Flores O, Rayle L (2017) How cities use regulation for innovation: the case of Uber, Lyft and sidecar in San Francisco. Transportation Research Procedia. (World Conference on Transport Research - WCTR 2016 Shanghai. 10-15 July 2016) 25:3756-3768. https://doi.org/10.1016/j.trpro.2017.05.232

19. Forum Virium Helsinki. 'What is CitySDK? - CitySDK'. Available at: //www. citysdk.eu/about-the-project/ (Accessed: 15 Sept 2017).

20. Gabel D (2016) Uber and the persistence of market power. J Econ Issues 50(2):527-534. https://doi.org/10.1080/00213624.2016.1179060

21. Geradin D (2015) Uber and the rule of law: should spontaneous liberalization be applauded or criticized? Compet Policy Int 11(1):22-29

22. Glaister S, Graham DJ (2006) Proper pricing for transport infrastructure and the case of urban road congestion. Urban Stud 43(8):1395-1418. https://doi. org/10.1080/00420980600776475

23. Guston DH (2014) Understanding "anticipatory governance". Soc Stud Sci 44(2):218-242. https://doi.org/10.1177/0306312713508669

24. Harris, M. (2016) 'Secretive alphabet division funded by Google aims to fix public transit in US', The Guardian, 27 June. Available at: http://www. theguardian.com/technology/2016/jun/27/google-flow-sidewalk-labscolumbus-ohio-parking-transit (Accessed: 6 Sept 2017)

25. Henderson J (2018) Google buses and uber cars. In: Ward K et al (eds) The Routledge Handbook on Spaces of Urban Politics. Routledge Handbooks Online, Abingdon. https://doi.org/10.4324/9781315712468-43

26. International Transport Forum Corporate Partnership Board (2015) Big Data and Transport. Understanding and assessing options. Corporate Partnership Board Report. International Transport Forum, OECD, Paris www.itf-oecd.org/ sites/default/files/docs/15cpb_bigdata_0.pdf (Accessed: 21 Sept 2018

27. International Transport Forum Corporate Partnership Board (2016) Appbased ride and taxi services - principles for regulation. International Transport Forum, OECD, Paris https://www.itf-oecd.org/app-based-ride-andtaxi-services-principles-regulation (Accessed: 25 Sept 2018

28. International Transport Forum Corporate Partnership Board (2016) Shared mobility. Innovation for liveable cities. OECD, Paris https://www.itf-oecd.org/sites/ default/files/docs/shared-mobility-liveable-cities.pdf (Accessed: 12 Sept 2017

29. 'Judgement: Uber London Ltd and Transport for London' (2018). Westminster Magistrates Court. Available at: https://tfl.gov.uk/cdn/static/ cms/documents/uber-licensing-appeal-final-judgment.pdf (Accessed: 14 Sept 2018)

30. Laybourn-Langton L (2017) Crossroads. Choosing a future for London's transport in the digital age. Institute for Public Policy Research, London https://www.ippr.org/files/publications/pdf/crossroads-choosing-a-future-forLondons-transport_March2017.pdf (Accessed: 3 Sept 2017
31. Lee, D. (2017) 'Uber chief executive Kalanick resigns', BBC News, 21 June. Available at: http://www.bbc.co.uk/news/business-40351859 (Accessed: 18 Sept 2017)

32. Li, S. (2016) How big is Didi Chuxing?, CNBC. Available at: https://www.cnbc com/2016/05/13/how-big-is-didi-chuxing.html (Accessed: 15 Sept 2017)

33. Lindblom CE (1959) The science of "muddling through". Public Adm Rev 19(2):79-88. https://doi.org/10.2307/973677

34. Lindblom CE (1979) Still muddling, not yet through. Public Adm Rev 39(6): 517-526. https://doi.org/10.2307/976178

35. Liston, B. (2016) Uber teams with Florida city on public transit test, Reuters. Available at: http://uk.reuters.com/article/us-uber-tech-subsidies/ uber-teams-with-florida-city-on-public-transit-test-idUKKCNOW52LQ (Accessed: 14 Sept 2017)

36. Morozov, E. (2016) 'Only a cash-strapped public sector still finds "smart" technology sexy', The Guardian, 10 September. Available at: http://www. theguardian.com/commentisfree/2016/sep/10/only-public-sector-findssmart-technology-sexy (Accessed: 11 Sept 2017).

37. Mundy, S. (2014) Setback for Uber as Seoul looks to ban driver-hailing app, financial times. Available at: https://www.ft.com/content/01d7a05e-10b411e4-812b-00144feabdc0 (Accessed: 3 September 2017)

38. Posen $H$ (2015) Ridesharing in the sharing economy: should regulators impose Über regulations on Uber? lowa Law Rev 101(Issue 1):405-433

39. Powell WW, DiMaggio P (eds) (1991) The new institutionalism in organizational analysis. University of Chicago Press, Chicago

40. Ramírez R, Wilkinson A (2016) Strategic reframing: the Oxford scenario planning approach. First edition. Oxford University Press, Oxford

41. Ranchordás S (2013) The whys and woes of experimental legislation. Theory Pract Legis 1(3):415-440. https://doi.org/10.5235/2050-8840.1.3.415

42. Ranchordas S (2015) Does sharing mean caring? Regulating innovation in the sharing economy. Minnesota J Law Sci Technol 16(1):414

43. Ranchordás S (2017) Digital agoras: democratic legitimacy, online participation and the case of Uber-petitions. Theory Pract Legis 5(1):31-54. https://doi.org/10.1080/20508840.2017.1279431

44. RDW (Netherlands Vehicle Authority) (2017) On board computers for taxis. Available at: https://www.rdw.nl/zakelijk/branches/fabrikanten-enimporteurs/english-information-about-typeapprovals/type-approval-forcomponents/on-board-computers-for-taxis (Accessed: 25 Sept 2018)

45. Rowe PCM (2017) Beyond Uber and Airbnb: the social economy of collaborative consumption'. Soc Med Soc 3(2):2056305117706784. https:// doi.org/10.1177/2056305117706784

46. Schneider H (2017) Uber: innovation in society. Palgrave Macmillan (Palgrave pivot), Cham

47. Secretaria Municipal da Fazenda, Prefeitura da Cidade de São Paulo (2017) Intensive Use of Urban Road Credit and payments system (Uso Intensivo do Viário Urbano Sistema de créditos e pagamentos - OTTCs). Available at: https:// www.prefeitura.sp.gov.br/cidade/secretarias/fazenda/servicos/index.php?p= 20210 (Accessed: 26 Sept 2018)

48. Simon H (1957) Administrative behavior : a study of decision-making processes in administrative organization. 2nd edn. Macmillan, New York

49. Slater C (1997) General motors and the demise of streetcars. Transp Q 51(3 Summer):45-66

50. Slavnic Z, Urban S (2018) Meandering rides of the Swedish taxi industry: flourishing entrepreneurship or ethnic segmentation? Int J Sociol Soc Policy 38(5/6):444-458. https://doi.org/10.1108/IJSSP-09-2017-0113

51. Smart Highways (2017) Uber "may lose London licence" | Smart Highways Magazine: Industry News. Available at: http://smarthighways.net/uber-maylose-london-licence/ (Accessed: 11 Sept 2017)

52. Smith A (1991) Inquiry into the nature and causes of the wealth of nations. Campbell (Everyman's library, London, p 11

53. Standing C, Standing S, Biermann S (2018) The implications of the sharing economy for transport. Transp Rev 0(0):1-17. https://doi.org/10.1080/ 01441647.2018.1450307

54. Sundararajan A (2017) The sharing economy: the end of employment and the rise of crowd-based capitalism. First MIT press paperback edition. The MIT Press, Cambridge

55. Sutherland W, Jarrahi MH (2018) The sharing economy and digital platforms: a review and research agenda. Int J Inf Manag 43:328-341. https://doi.org/10.1016/i.ijinfomgt.2018.07.004

56. Tham A (2016) When Harry met Sally: different approaches towards Uber and AirBnB — an Australian and Singapore perspective. Inf Technol Tour 16(4):393-412. https://doi.org/10.1007/s40558-016-0070-3 
57. Topham, G., Hellier, D. and Gani, A. (2015) 'Uber wins high court case over taxi app', The Guardian, 16 October. Available at: http://www.theguardian. com/technology/2015/oct/16/uber-wins-high-court-case-taxi-app-tfl (Accessed: 13 Sept 2017)

58. Transport for London (2016) Travel in London. Report 9. Transport for London, London https://tfl.gov.uk/cdn/static/cms/documents/travel-inlondon-report-9.pdf (Accessed: 13 Sept 2017

59. Transport for London (2017) Licensing decision on Uber London Limited, Transport for London. Available at: https:/ttll.gov.uk/info-for/media/pressreleases/2017/september/licensing-decision-on-uber-london-limited (Accessed: 27 Sept 2017)

60. Tsang, A. (2017) 'Morning agenda: Uber's Maverick leader', The New York Times, 24 April. Available at: https://www.nytimes.com/2017/04/24/business/ dealbook/uber-apple-kalanick-att.html (Accessed: 13 Sept 2017)

61. Uber (2017) A Cleaner Future for our Cities, Uber Blog. Available at: https://www.uber.com/en-GB/blog/a-cleaner-future-for-our-cities/ (Accessed: 14 Sept 2017)

62. Uber (2018) How surge pricing works. Available at: https://www.uber.com/ en-GB/drive/partner-app/how-surge-works/ (Accessed: 24 Sept 2018)

63. Uber. Moving Florida. Available at: https://www.uber.com/info/florida/ (Accessed: 14 Sept 2017).

64. Van der Heijden K (1996) Scenarios: the art of strategic conversation. Wiley, Chichester, New York

65. Wack P (1985) Scenarios: uncharted waters ahead. Harv Bus Rev:73-89

66. Walker Smith J (2016) The Uber-all economy of the future. Indep Rev 20(3):383-390

67. Walters, M. (2017) Uber suffers EU court setback, news | law society gazette. Available at: https://www.lawgazette.co.uk/law/uber-suffers-eu-courtsetback/5061070.article (Accessed: 13 Sept 2017)

68. Watanabe $C$ et al (2017) Consolidated challenge to social demand for resilient platforms - lessons from Uber's global expansion. Technol Soc 48: 33-53. https://doi.org/10.1016/j.techsoc.2016.10.006

\section{Submit your manuscript to a SpringerOpen ${ }^{\circ}$ journal and benefit from:}

- Convenient online submission

- Rigorous peer review

- Open access: articles freely available online

High visibility within the field

- Retaining the copyright to your article

Submit your next manuscript at $\boldsymbol{\nabla}$ springeropen.com 